\title{
Soil, snow, weather, and sub-surface storage data from a mountain catchment in the rain-snow transition zone
}

\author{
P. R. Kormos ${ }^{1}$, D. Marks ${ }^{2}$, C. J. Williams ${ }^{2}$, H. P. Marshall ${ }^{1}$, P. Aishlin ${ }^{1}$, D. G. Chandler ${ }^{3}$, and \\ J. P. McNamara ${ }^{1}$ \\ ${ }^{1}$ Boise State University, Department of Geosciences, 1910 University Dr., Boise, Idaho 83725, USA \\ ${ }^{2}$ Agricultural Research Service, Northwest Watershed Research Center, 800 Park Blvd., Plaza IV, Suite 105 \\ Boise, Idaho 83712, USA \\ ${ }^{3}$ Syracuse University, L.C. Smith College of Engineering and Computer Science, 151 Link Hall, 900 South \\ Crouse Ave., Syracuse, New York 13244, USA \\ Correspondence to: J. P. McNamara (jmcnamar@boisestate.edu)
}

Received: 13 September 2013 - Published in Earth Syst. Sci. Data Discuss.: 3 December 2013

Revised: 23 March 2014 - Accepted: 26 March 2014 - Published: 28 April 2014

\begin{abstract}
A comprehensive hydroclimatic data set is presented for the 2011 water year to improve understanding of hydrologic processes in the rain-snow transition zone. This type of data set is extremely rare in scientific literature because of the quality and quantity of soil depth, soil texture, soil moisture, and soil temperature data. Standard meteorological and snow cover data for the entire 2011 water year are included, which include several rain-on-snow (ROS) events. Surface soil textures and soil depths from 57 points are presented as well as soil texture profiles from 14 points. Meteorological data include continuous hourly shielded, unshielded, and wind-corrected precipitation, wind speed and direction, air temperature, relative humidity, dew point temperature, and incoming solar and thermal radiation data. This data is often viewed as "forcing data", and is gap filled and serially complete. Sub-surface data included are hourly soil moisture data from multiple depths from seven soil profiles within the catchment, and soil temperatures from multiple depths from two soil profiles. Hydrologic response data include hourly stream discharge from the catchment outlet weir, continuous snow depths from one location, intermittent snow depths from 5 locations, and snow depth and density data from ten weekly snow surveys. Snow and hydrologic response data are meant to provide data on the catchment hydrologic response to the weather data. This data is mostly presented "as measured" although snow depths from one sensor and streamflow at the catchment outlet have been gap filled and are serially complete. Though the weather, snow, and hydrologic response data only covers one water year, the presentation of the additional subsurface data (soil depth, texture, moisture, and temperature) makes it one of the most detailed and complete hydro-climatic data sets from the climatically sensitive rain-snow transition zone. The data presented are appropriate for a wide range of modeling (energy balance snow modeling, soil capacitance parametric modeling, etc.) and descriptive studies. Data is available at doi:10.1594/PANGAEA.819837.
\end{abstract}

\section{Introduction}

Detailed weather, soils, and hydrologic response data are presented that provide a whole-catchment view of the dynamic hydrology that occurs in the mountain rain-snow transition zone. We define the rain-snow transition zone as the elevation band in temperate mountains where the dominant winter precipitation phase is variable, and changes from rain at lower elevations to snow at higher elevations. Precipitation can transition between phases during storms, but the snow line exists within the rain-snow transition zone. It may approach sea level at high latitudes (Feiccabrino et al., 2012), but can frequently extend above $2000 \mathrm{~m}$ at lower latitudes (Cayan et al., 2001). In the interior Pacific Northwest, US, where this data collection effort was conducted, 
Table 1. Hydro-meteorological parameters, type of instruments, and instrument heights from the Treeline experimental catchment in WY2011. Locations are denoted by WS - weather station, 4CR - four component radiometer, Npit3 - north soil pit 3, OF - outlet flume.

\begin{tabular}{|c|c|c|}
\hline $\begin{array}{l}\text { Hydro-meteorological } \\
\text { parameter }\end{array}$ & $\begin{array}{l}\text { Method/ } \\
\text { instrument }\end{array}$ & $\begin{array}{r}\text { Sensor } \\
\text { height }(\mathrm{m})\end{array}$ \\
\hline Shielded precipitation (WS) & 8 inch Belfort-type gauge with Alter Shield & 2 \\
\hline Unshielded precipitation (WS) & 8 inch Belfort-type gauge & 2 \\
\hline Wind-corrected precipitation & (Hanson, 2004) & 2 \\
\hline Wind speed (WS) & Met One WS 013 & 2 \\
\hline Wind direction (WS) & Met One WD 023 & 2 \\
\hline Air temperature (WS) & Vaisala HMP45AC & 2 \\
\hline Humidity (WS) & Vaisala HMP45AC & 2 \\
\hline Incoming solar (WS) & Matrix Mk 1-G & 2 \\
\hline Incoming \& outgoing solar (4CR) & Hukseflux NR01 & 2 \\
\hline Incoming \& outgoing thermal (4CR) & Hukseflux NR01 & 2 \\
\hline Soil temperature (Npit3) & CS 107 thermistor & -0.05 \\
\hline Stream discharge $(\mathrm{OF})$ & Druck PDCR1830 in v-notch flume & na \\
\hline
\end{tabular}

Table 2. Distributed watershed data, number of sensors, type of instruments, and instrument heights from the Treeline experimental catchment for WY2011.

\begin{tabular}{lllr}
\hline Number & Variable & Measurement method & Heights (m) \\
\hline 2 profiles & soil temperature & CS 107 thermistor & -0.05 to -1.00 \\
2 profiles & soil moisture & CS 615 soil moisture probe & -0.05 to -1.00 \\
5 profiles & soil moisture & CS TDR100 soil moisture probe & -0.09 to -1.01 \\
1 sensor & snow depth & Judd depth sensor & 2 \\
5 sensors & snow depth & MaxBotix XL-MaxSonar EZ2 (self-made) & 2 \\
10 surveys & snow depth & various & na \\
10 surveys & snow density & various & na \\
57 points & soil depth & steel rod pounded to refusal & -0.24 to -1.25 \\
57 points & soil texture & sieve and hydrometer & 0.00 to -0.30 \\
14 profiles & soil texture & sieve and hydrometer & 0.00 to -0.81 \\
\hline
\end{tabular}

the rain-snow transition typically occurs in mid-elevations ranging from 1500-1800 $\mathrm{m}$ (Nayak et al., 2010). Nolin and Daily (2006) estimated that currently the rain-snow transition zone covers approximately $9200 \mathrm{~km}^{2}$ in the Pacific Northwest. This is a region where warming trends are expected to shift the current precipitation regime toward being rain-dominated and move the rain-snow transition to higher elevations.

The mountain rain-snow transition zone is an important area for study because it is sensitive to warming trend effects on the snow cover (Mote, 2003) and ecosystems (Cayan et al., 2001; Cuo et al., 2011). The snow cover in this zone is sensitive to climate warming trends because it is generally warm and ephemeral. The presence or absence of snow impacts the energy and mass balance because it dictates whether incoming solar radiation is reflected or absorbed. Since precipitation can be deposited as either rain that is rapidly transmitted to the soil, or snow that delays the delivery of liquid water to the soil, changes in the precipitation phase translate directly to changes in the timing of water inputs to catchment soils. Weather and soil data sets have been published from rain-dominated (Western and Grayson, 1998) and snow-dominated areas (Reba et al., 2012; Seyfried et al., 2001b; Seyfried et al., 2001a; Morin et al., 2012), but there is a general lack of data from the rain-snow transition zone.

Seven ROS events, which are known to create large amounts of runoff from the combined volume of rain and rapid melt, were recorded in the data presented in this paper. These events often contribute to record floods (Surfleet and Tullos, 2013; Marks et al., 1998; Kattelmann, 1996; McCabe et al., 2007; Harr, 1986; Sui and Koehler, 2001) and can cause major avalanche cycles (e.g., Conway and Raymond, 1993). One of the ROS events presented here caused the peak measured stream discharge (1998-2013) for the catchment studied here. ROS events in this region are common, but having them occur over a specific site under optimal measurement conditions is a matter of timing and luck. For example, Marks et al. (2013) established a transect of measurement sites every $50 \mathrm{~m}$ across $380 \mathrm{~m}$ of elevation (1488-1868 m) to monitor the transition between rain and snow. Though there were many precipitation occurrences, only a few significant 


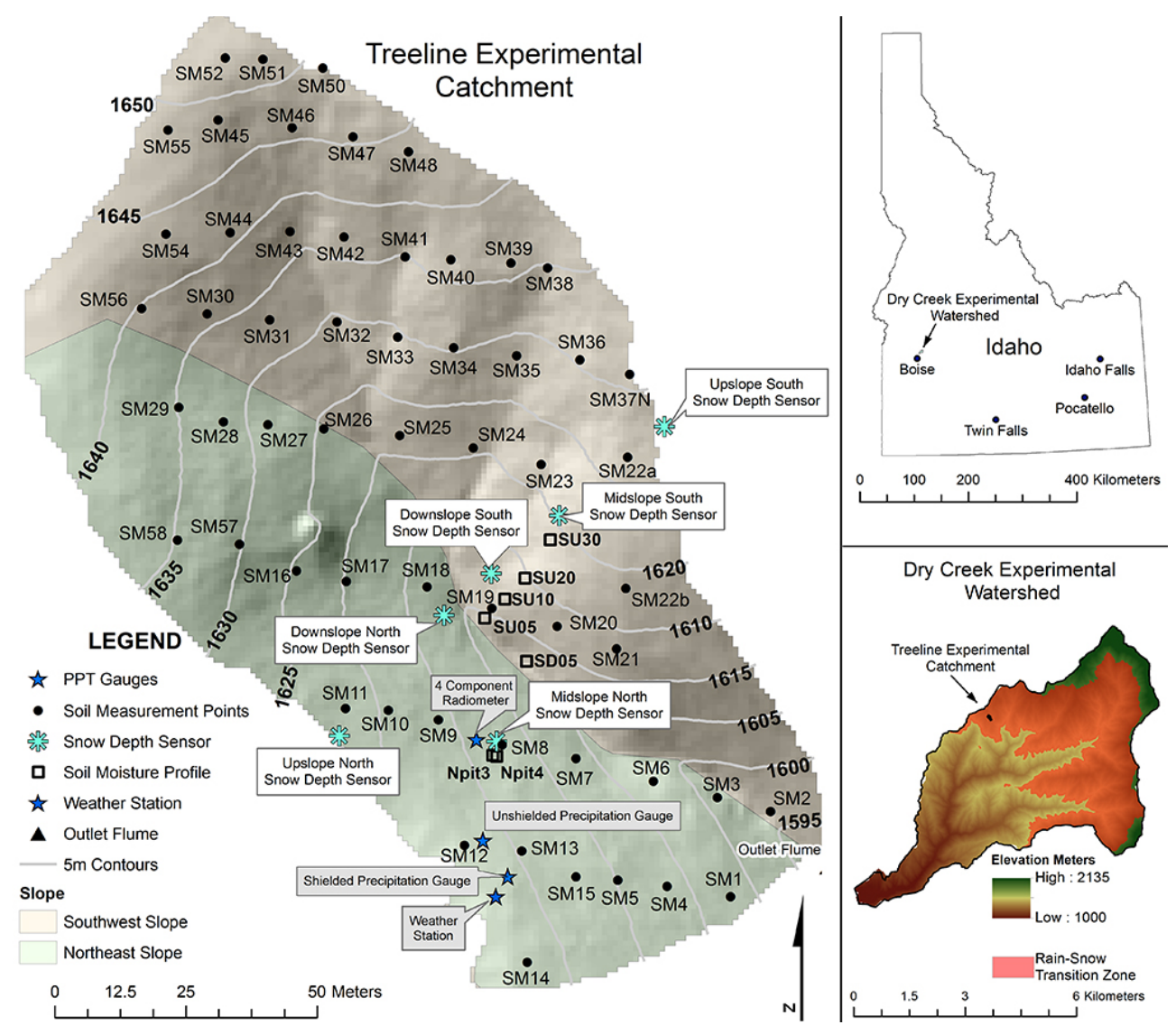

Figure 1. Location map of the Treeline experimental catchment in the Dry Creek experimental watershed and the location of instruments and measurement points.

mixed phase events were directly measured during the ten years in which the transect was operated (2004-2013).

Catchment data are presented for the Treeline (TL) experimental catchment for the 2011 water year (WY2011: 1 October 2010-30 September 2011) (Fig. 1). The study area is unique because it is located at both a climatic transition between rain and snow, and a vegetation transition between shrub lands and forests. The catchment is instrumented specifically to quantify the distribution of precipitation, snow cover, and soil moisture. Table 1 summarizes the hydro-meteorological parameters presented and Fig. 1 locates catchment instrumentation. Table 2 summarizes the distributed watershed data presented.

The data set provides a high-resolution, fine-scale set of observations that offer a broad spectrum of researchers an opportunity to study a host of topics associated with water storage and flux in a small catchment. Model developers can use distributed soil and topographic data to obtain state variables, serially complete and gap filled weather data to drive, and snow, soil moisture, and streamflow data to evaluate the model performance. Detailed topographic data combined with soil moisture measurements can be used to evaluate the underlying topographic indices commonly used in
Table 3. Soil profile names, aspects, and sensor depths.

\begin{tabular}{lcr}
\hline Profile name & Aspect & Sensor depths (cm) \\
\hline Npit3 & NE & $5,15,60,100$ \\
Npit4 & NE & $5,15,30,45,65$ \\
SD05 & SW & 15,101 \\
SU05 & SW & 9,27 \\
SU10 & SW & 15,52 \\
SU20 & SW & 12,34 \\
SU30 & SW & 18,70 \\
\hline
\end{tabular}

many empirical streamflow models (O'Loughlin, 1981 and 1986; Beven and Kirkby, 1979). Soil moisture redistribution algorithms that account for diffuse and preferential flow can be tested to evaluate the timing of soil moisture responses at depths.

\section{Catchment description}

TL is a 1.5 hectare $\left(0.015 \mathrm{~km}^{2}\right)$ catchment of the Dry Creek Experimental Watershed (DCEW) established in 1999 to study hydrologic processes in semiarid mountains. The 

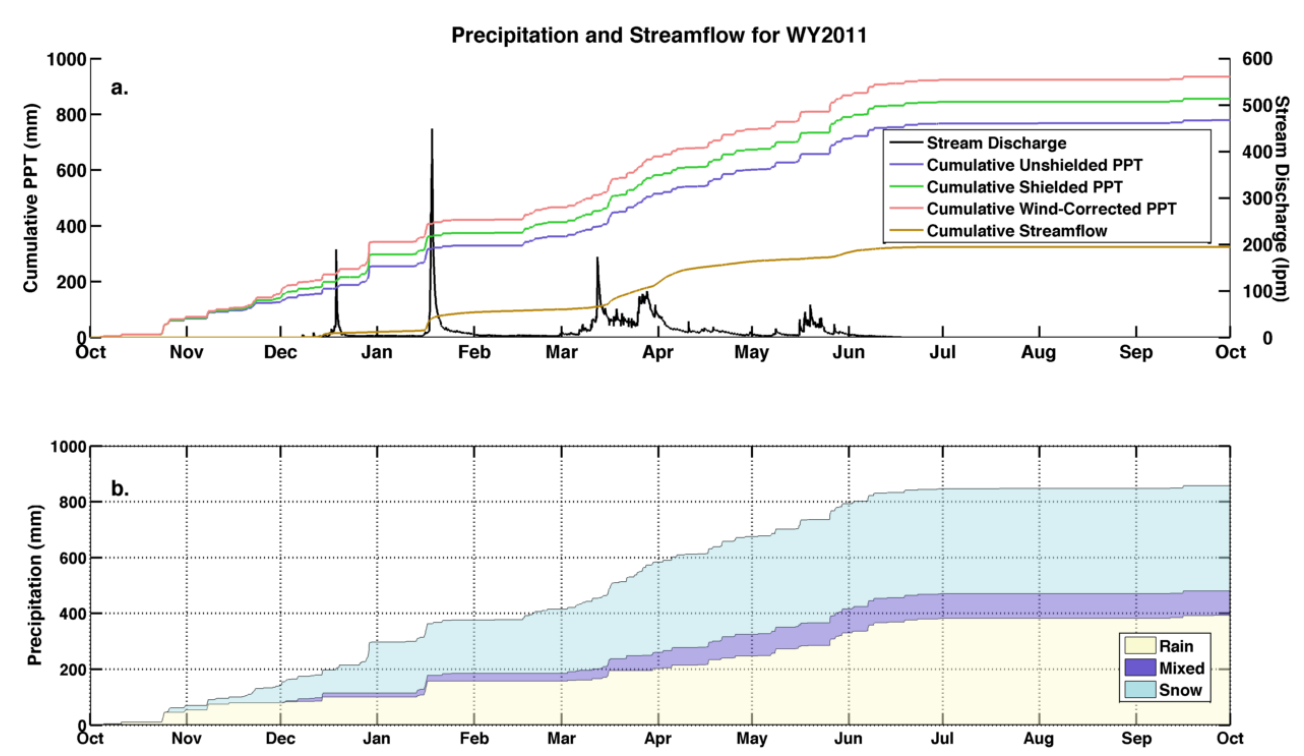

Figure 2. Precipitation and streamflow from the Treeline experimental catchment for WY2011. Cumulative shielded, unshielded, and windcorrected precipitation with cumulative streamflow and the hydrograph are presented in (a). The phase of cumulative wind-corrected precipitation based on dew point temperature is presented in (b).

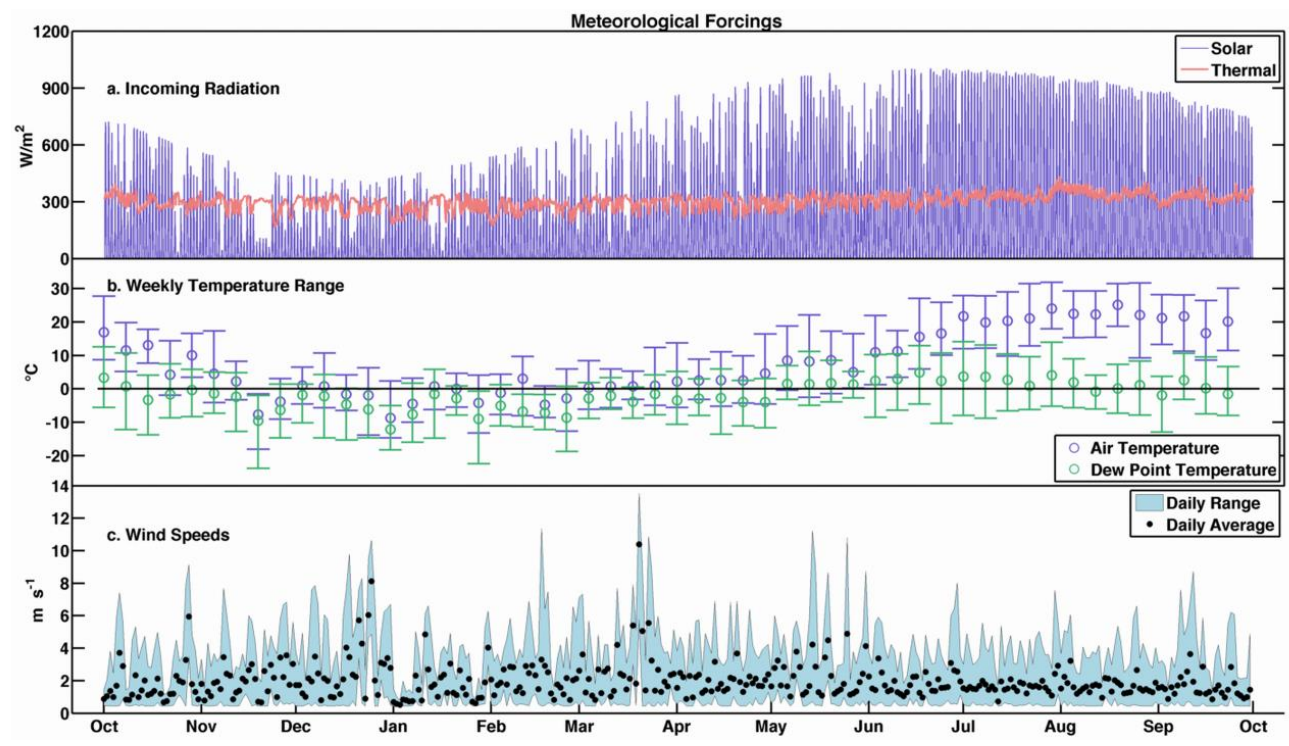

Figure 3. Weather data measured at the Treeline experimental catchment for WY2011. (a) presents incoming measured and gap-filled solar and thermal radiation. (b) presents weekly average, minimum, and maximum air and dew point temperatures. (c) presents measured daily average, minimum, and maximum wind speeds.

extent of TL is defined by the location of a v-notch weir where catchment streamflow is measured (Fig. 1). The elevation ranges from 1600 to $1645 \mathrm{~m}$ a.s.l. and the mean slope is $21^{\circ}$. Vegetation is typical of a transition between lower elevation grasslands and higher elevation forests, with steep slopes and stark differences between aspects (Williams et al., 2009). The northeast facing slope is typified by sagebrush, ceanothus shrubs, prunus ssp., forbs, and grasses with a mean canopy height of $0.7 \mathrm{~m}$. Southwest facing slopes have simi- lar but sparser vegetation with a mean height of $0.3 \mathrm{~m}$. There are eight mature conifer trees in the catchment. Streamflow in upland ephemeral streams is disconnected from deep, regional groundwater (Miller et al., 2008), perhaps due to high bedrock hydraulic conductivity, which has been estimated at $10.93 \mathrm{~m} \mathrm{~s}^{-1}$ (Hoffman, 2008). Soils are thin (20$125 \mathrm{~cm}$ ), range from loam to sandy-loam, and overlie fractured granitic bedrock (Gribb et al., 2009; Yenko, 2003). Basins with ephemeral streams such as TL are important 


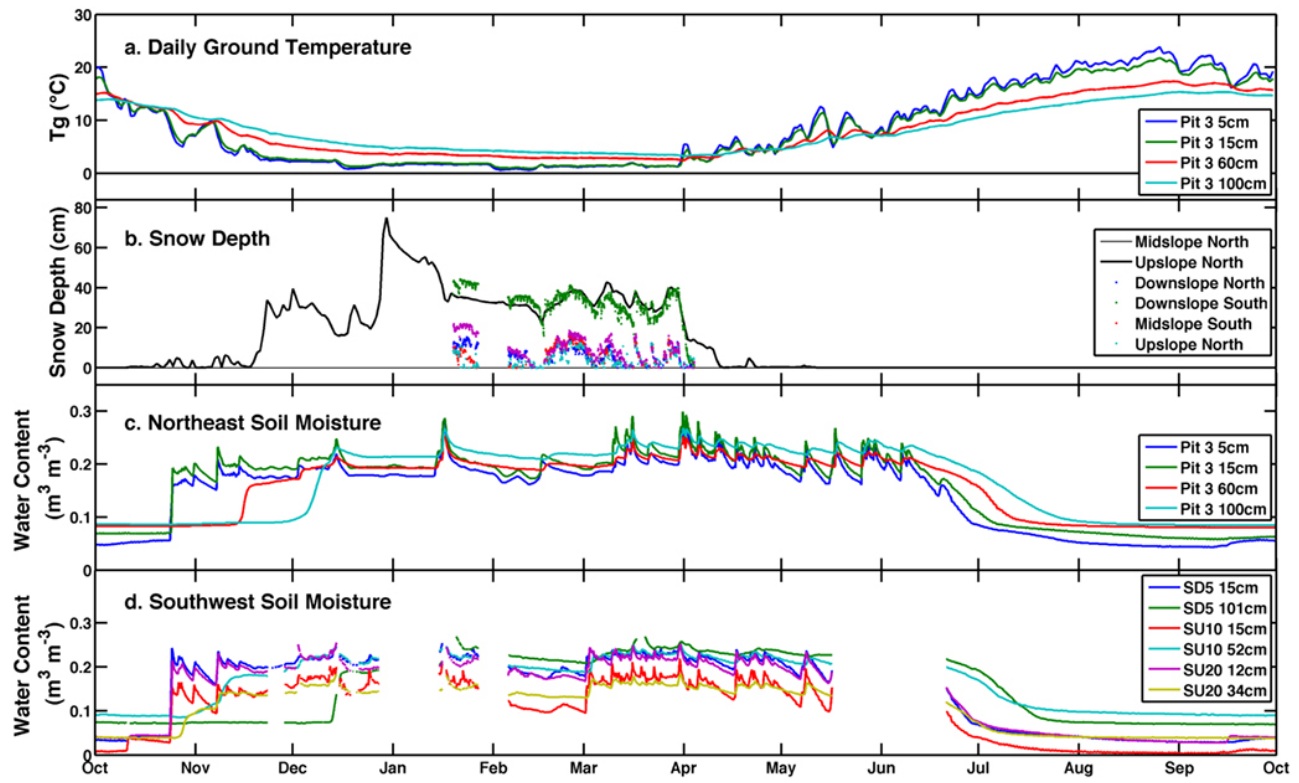

Figure 4. Soil and snow data from the Treeline experimental catchment for WY2011. Daily average soil temperature (a) and moisture (c) from pit 3 on the northeast facing slope, and soil moisture from several pits from the southwest facing slope (d) are presented. Snow depths from six locations are presented in (b).

sources of groundwater recharge (Aishlin and McNamara, 2011). Several studies have shown aspect differences on soil properties (Geroy et al., 2011; Tesfa et al., 2009; Smith et al., 2011).

\section{Weather data}

Weather data represent typical hydrological model forcing parameters, and include precipitation, solar and thermal radiation, air temperature and humidity, wind speed and direction, and soil temperature. All weather data are hourly and serially complete for the entire WY2011. Data gaps have been filled using the most appropriate of either linear interpolation, or linear regression to nearby measurements of the same parameter.

Precipitation. Shielded and unshielded precipitation were measured at TL using Belfort-type gauges (Hanson et al., 2001), filtered following Nayak et al. (2008), and wind corrected using the protocol of Hanson et al. (2004). Precipitation and the stream hydrograph from the outlet weir are shown in Fig. 2a. The phase of cumulative wind-corrected precipitation based on dew point temperatures is shown in Fig. 2b (Marks et al., 2013).

Radiation. Serially complete incoming shortwave and longwave radiation time series are presented in WEATHER_DATA.txt in the Supplement. Incoming and outgoing shortwave and longwave radiation data, as measured at the four component radiometer, is presented in FOUR_COMPONENT_RAD.txt in the Supplement and are not gap filled. Shortwave radiation was measured by two pyranometers at the TL weather station. A continuous hourly time series was generated using data from the two instruments, but favoring the more recently calibrated Huxeflux NR01 (Table 1). Incoming longwave radiation was measured by the four-component radiometer. Gaps in the measured longwave radiation record were substantial $(48 \%)$ and were filled using data from a pyrgeometer at $1720 \mathrm{~m}$ a.s. $1.3 .8 \mathrm{~km}$ away within DCEW. Figure 3a presents the water year time series of incoming shortwave and longwave irradiance.

Air Temperature and Humidity. Air temperature $\left(T_{\mathrm{a}}\right)$ and relative humidity $(\mathrm{RH})$ were measured at the TL weather station. $T_{\mathrm{a}}$ and $\mathrm{RH}$ were converted to dew point temperature $\left(T_{\mathrm{d}}\right)$ using methods developed by Marks et al. (1999), as applied and described by Reba et al. (2011). Figure 3b presents weekly minimum, maximum, and mean $T_{\mathrm{a}}$ and $T_{\mathrm{d}}$ for WY2011, which was a cooler year than average. The mean $T_{\mathrm{a}}$ was $7.9^{\circ} \mathrm{C}$ compared to the period of record mean, which was $9.3^{\circ} \mathrm{C}$. The maximum $T_{\mathrm{a}}$ of $31.8^{\circ} \mathrm{C}$ was reached in late August while the minimum air $T_{\mathrm{a}}$ of $-18.1^{\circ} \mathrm{C}$ was reached in late November. WY2011 was wetter than average with a mean $T_{\mathrm{d}}$ of $-1.67^{\circ} \mathrm{C}$ compared to the period of record mean of $-2.24^{\circ} \mathrm{C}$. The maximum $T_{\mathrm{d}}$ of $14.1^{\circ} \mathrm{C}$ was reached in July, while the minimum $T_{\mathrm{d}}$ of $-23.8^{\circ} \mathrm{C}$ was reached in November. The dew point temperature was close to zero for much of the winter, demonstrating the sensitivity of the precipitation phase at this study location to changes in humidity and temperature.

Wind Speed and Direction. Wind speed $(u)$ and direction (v) were measured at the TL weather station. Hourly $u$ and $v$ data are serially complete for WY2011. $u$ ranges from 0 


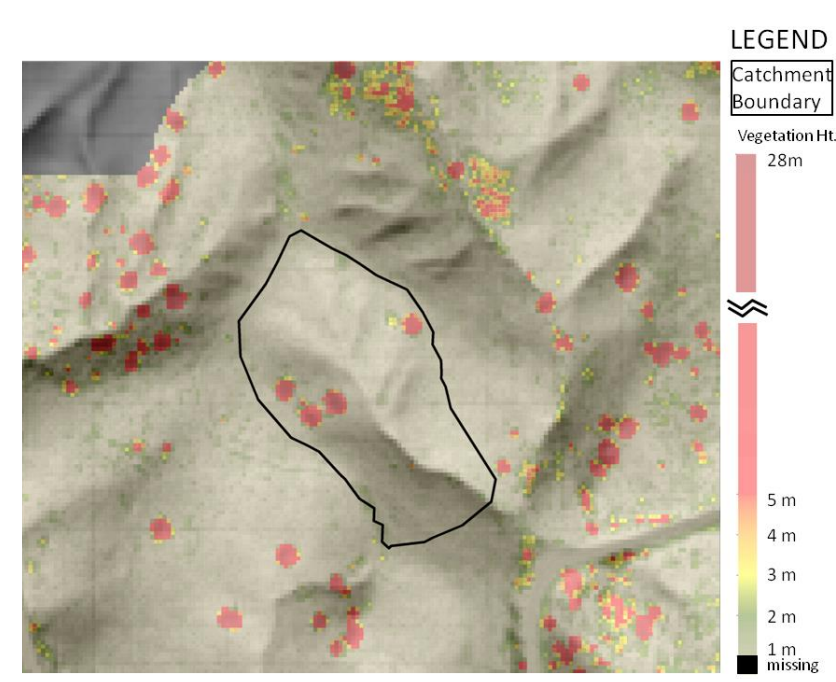

Figure 5. Aerial lidar-derived vegetation height over shaded topographic relief map.

to $13.5 \mathrm{~m} \mathrm{~s}^{-1}$. Figure $3 \mathrm{c}$ presents daily $u_{\max }, u_{\min }$, and $u_{\mathrm{avg}}$ for WY2011. Wind speeds for WY2011 do not show a pronounced difference between storm and non storm time periods. Both have median values of approximately $1.5 \mathrm{~m} \mathrm{~s}^{-1}$. Storm $v$ is typically out of the southwest and ranges from $175^{\circ}$ to $250^{\circ}$ during winter storms, which agrees with work in nearby areas (Winstral et al., 2013).

Soil Temperature. Soil temperature profiles are measured at all profile depths from Npit3 and Npit4 (Fig. 1, Table 3). Figure $4 \mathrm{a}$ and $\mathrm{b}$ present mean daily soil temperature profile data from Npit3 and mean daily snow depth, respectively.

\section{Spatial characterization data}

Characterization data are used to define the structure, composition, land cover, soil structure and hydrologic properties of the TL catchment. These data provide the fine-scale detail required for modeling and hydrologic assessment.

\subsection{Soil data}

Soil depth and soil texture from the top $30 \mathrm{~cm}$ were obtained at 57 points across TL, representing the full range of exposures, slopes, and elevations in the catchment. Soil depths were measured by pounding a steel rod to refusal and soil texture was acquired by sieving core samples (mean sample size of $4.7 \mathrm{~g}$ ) as described by Williams et al. (2009). In addition, soil texture data from several depths at 14 locations are presented. Soil moisture data is presented that is collocated with texture profiles at locations SD05, SU05, SU10, SU20, and SU30 as described in the hydrologic response section of this paper.

\subsection{GIS data}

Terrain elevation and structure are derived from an aerial lidar data set acquired in 2009 and processed using Idaho State University's publicly available lidar processing tools (http://bcal.geology.isu.edu/tools/lidar) as described in Streutker and Glen (2006). The processed TL GIS data includes four components: (1) a $2.5 \mathrm{~m}$ bare earth digital elevation model (DEM), from which (2) the catchment boundary is derived, GIS layers of (3) vegetation height, and (4) instrument and soil measurement locations. Figure 5 presents a shaded relief image of the TL catchment, with overlying vegetation height.

\section{Snow and hydrologic response data}

\subsection{Snow depth}

Hourly snow depth was recorded by a depth sensor located mid-slope on the northeast facing slope (Fig. 1). These data were processed and cleaned, and are serially complete for WY2011. Figure $4 \mathrm{~b}$ presents mean daily values for these data. Five additional ultrasonic snow depth sensors are located in a transect that covers the two dominant basin aspects (Fig. 1). Due to instrument malfunctions, only intermittent snow depth data from these 5 sensors are available from 19 January 2011 through melt-out (Fig. 4b).

\subsection{Snow survey data}

A series of ten weekly snow surveys was completed from 21 January to 24 March 2011. Surveys were designed to capture snow depth and snow water equivalent differences within the catchment (Winstral and Marks, 2014) based on lidar derived depth similarity classes (Shallcross, 2012). This knowledge of typical snow distribution and variance at TL allowed us to characterize the catchment snow storage by sampling a small portion of the catchment area. Between five and nine snow density samples were collected across the two predominant aspects on each survey day and were used to convert snow depth to SWE. Density measurements were taken with a federal-type tube, density cutter, or new snow tube depending on conditions (Judson and Doesken, 2000; Conger and McClung, 2009). Density measurements are depth-integrated values and vary greatly on days where new snow is deposited on both bare ground and on the preexisting snowpack. A minimum of 105 depths were recorded in five transects each week, and the use of a Magnaprobe (SnowHydro, www.snowhydro.com) for seven out of the ten surveys enabled the collection of an average of 250 depths. Table 4 presents the number and method of measurements for each survey. Snow depth is presented as gridded average data (Fig. 6). Gridded data also include the number of depth measurements and standard deviation at each grid cell. 
Table 4. Summary of snow survey data including the date, and number and method of snow depth and density measurements.

\begin{tabular}{lclcl}
\hline $\begin{array}{l}\text { Survey } \\
\text { date }\end{array}$ & $\begin{array}{c}\text { Number of } \\
\text { snow depth } \\
\text { measurements }\end{array}$ & Method & $\begin{array}{c}\text { Number of } \\
\text { snow density } \\
\text { measurements }\end{array}$ & Method \\
\hline $1 / 21 / 11$ & 108 & manual probe & 7 & federal tube \\
$1 / 28 / 11$ & 248 & Magnaprobe & 9 & federal tube \\
$2 / 4 / 11$ & 262 & Magnaprobe & 9 & federal tube/new snow tube \\
$2 / 11 / 11$ & 395 & Magnaprobe & 9 & density cutter/new snow tube \\
$2 / 18 / 11$ & 377 & Magnaprobe & 9 & density cutter \\
$2 / 25 / 11$ & 155 & Magnaprobe & 9 & federal tube \\
$3 / 4 / 11$ & 349 & Magnaprobe & 7 & federal tube \\
$3 / 11 / 11$ & 105 & manual probe & 8 & federal tube/density cutter \\
$3 / 17 / 11$ & 300 & Magnaprobe & 6 & federal tube \\
$3 / 24 / 11$ & 245 & Magnaprobe & 5 & federal tube \\
\hline
\end{tabular}

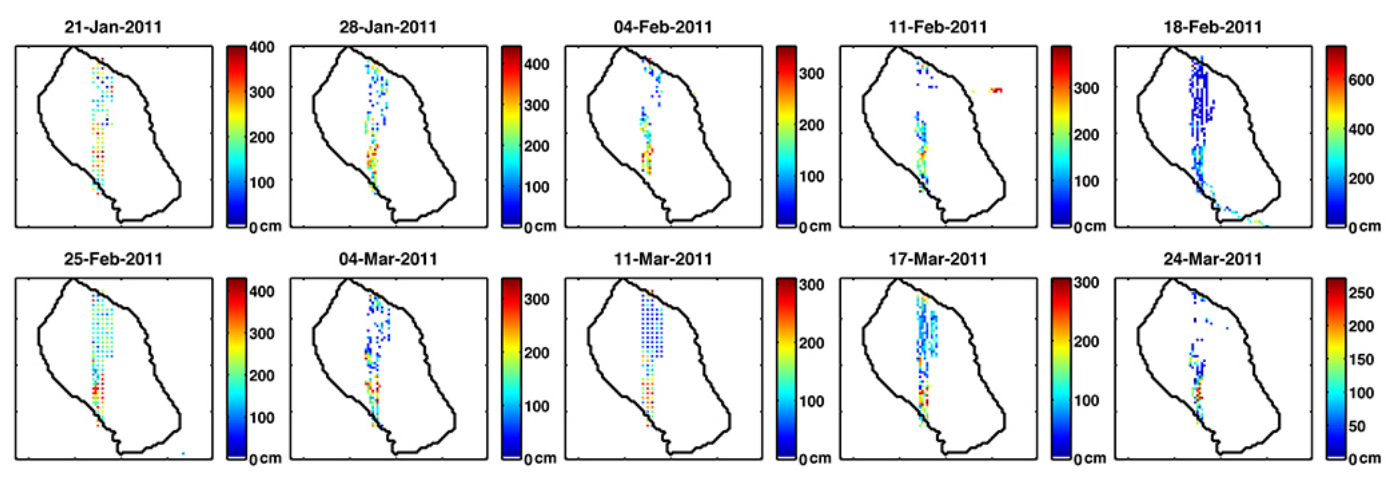

Figure 6. Gridded mean snow depth from 10 snow surveys.

\subsection{Stream discharge}

Stream discharge is derived from stage recorded with a pressure transducer in a v-notch weir at the catchment outlet. The stream that drains TL is intermittent and initiates in the fall when snow cover is established and dries out in early to midsummer. Stream ice is rarely a hindrance to streamflow measurement as the stream is commonly insulated from brief extreme low temperatures by the snowpack. Due to equipment malfunctions, continuous stage measurements begin on 16 December and continue through the cessation of streamflow. Discharge was estimated for the period prior to December 16 from a series of manual measurements and by developing a relationship between stage at the TL weir and data from other nearby weirs within DCEW over the ten years of record. The average WY2011 stream discharge at the TL weir is $9.3 \mathrm{~L}$ per minute. The streamflow peak of record was caused by a ROS event on 16 January 2011, which resulted in a high flow of $449.3 \mathrm{~L}$ per minute. Figure 2a presents streamflow from the TL catchment.

\subsection{Soil moisture}

Soil moisture is recorded at two depths at five southwest facing soil moisture profiles and at four and five depths at two northeast facing soil pits (Fig. 1, Table 3). TL soil moisture dynamics is described by McNamara et al. (2005). The coarse texture of TL soils leads to relatively rapid drainage when field capacity is exceeded. The semi-arid plant community draws soil moisture down quickly during spring greenup, but is slowed by spring rain events. Data from Npit3 and Npit4 are hourly and serially complete. Due to instrument malfunctions, gaps exist in soil moisture data from SD05, SU05, SU10, SU20, and SU30, as is typified in Fig. 4d. Figure $4 \mathrm{c}$ and $\mathrm{d}$ present soil moisture data from Npit3 on the northeast facing slope and profiles SD05, SU10, and SU20 on the southwest facing slope. Shallow probes may be influenced by evaporation from the soil surface. Deepest sensors at all profiles were placed at the soil-bedrock interface, and may measure soil moisture increased due to the collection of water at the soil-bedrock interface, or the influence of lateral flow from upslope contributing areas.

\section{Data availability}

All data presented in this paper are available from the PANGAEA ${ }^{\circledR}$ website (doi:10.1594/PANGAEA.819837). Included are readme files in each directory listing the data contents, a detailed description of data, and contact information 
for additional details. Additional weather and hydrologic response data for the Treeline catchment and other catchments within the Dry Creek experimental watershed are available at http://earth.boisestate.edu/drycreek/data/ and through the CUAHSI Hydrologic Information System.

\section{Summary}

Data presented in this paper are unique because (1) they capture complicated snow-soil-streamflow dynamics from the climatically sensitive rain-snow transition zone, and (2) they present a complete representation of the data required to characterize the hydrologic processes in this catchment. Spatial GIS data are derived from a lidar data set and represent the TL catchment topography and vegetation at a $2.5 \mathrm{~m}$ resolution. In all, 57 surface soil texture data points and 14 soil texture profiles are presented. Hourly weather data have been gap filled and are continuous. Snow cover data are extensive and include continuous snow depths from 6 locations and 10 detailed weekly snow surveys. Catchment response data include stream discharge at the basin outlet and soil moisture from multiple depths at seven locations in the basin.

\section{Supplementary material related to this article is available online at http://www.earth-syst-sci-data.net/6/ 165/2014/essd-6-165-2014-supplement.zip.}

Acknowledgements. We thank M. Seyfried and A. Winstral for assisting in the preparation of this manuscript, L. Spaete at Boise Center Aerospace Laboratory with lidar processing, J. Huntington for soil profile installation, E. Boe for snow depth data, and M. Gribb for soil texture analysis. We thank the Northwest Watershed Research Center and Boise State University Department of Geosciences, Student Research Initiative, and Graduate College for funding and travel support, and general support. NASA EPSCoR and INRA provided funding for this project. The collection and processing of the data presented in this paper were funded in part by NSF-CBET (0854553, 08522), USDA-ARS CRIS Snow and Hydrologic Processes in the Intermountain West (5362-13610008-00D), USDA-NRCS Water and Climate Center-Portland, Oregon (5362-13610-008-03R), NSF-EPS (0919514), and NOAA (NA08NWS4620047). Any reference to specific equipment types or manufacturers is for information purposes and does not represent a product endorsement or recommendation. Boise State University and the USDA ARS are equal opportunity employers.

Edited by: A. Gelfan

\section{References}

Aishlin, P. and McNamara, J. P.: Bedrock infiltration and mountain block recharge accounting using chloride mass balance, Hydrol. Process., 25, 1934-1948, doi:10.1002/hyp.7950, 2011.
Beven, K. and Kirkby, M.: A physically based, variable contributing area model of basin hydrology/Un modèle à base physique de zone d'appel variable de l'hydrologie du bassin versant, Hydrolog. Sci. J., 24, 43-69, 1979.

Cayan, D. R., Kammerdiener, S. A., Dettinger, M. D., Caprio, J. M., and Peterson, D. H.: Changes in the onset of spring in the western United States, B. Am. Meteorol. Soc., 82, 399-415, doi:10.1175/1520-0477(2001)082<0399:citoos>2.3.co;2, 2001.

Conger, S. M. and McClung, D. M.: Comparison of density cutters for snow profile observations, J. Glaciol., 55, 163-169, doi:10.3189/002214309788609038, 2009.

Conway, H. and Raymond, C. F.: Snow stability during rain, J. Glaciol., 39, 635-642, 1993.

Cuo, L., Beyene, T. K., Voisin, N., Su, F., Lettenmaier, D. P., Alberti, M., and Richey, J. E.: Effects of mid-twenty-first century climate and land cover change on the hydrology of the Puget Sound basin, Washington, Hydrol. Process., 25, 1729 1753, doi:10.1002/hyp.7932, 2011.

Feiccabrino, J., Lundberg, A., and Gustafsson, D.: Improving surface-based precipitation phase determination through air mass boundary identification, Hydrol. Res., 43, 179-191, doi:10.2166/nh.2012.060, 2012.

Geroy, I. J., Gribb, M. M., Marshall, H. P., Chandler, D. G., Benner, S. G., and McNamara, J. P.: Aspect influences on soil water retention and storage, Hydrol. Process., 25, 3836-3842, doi:10.1002/hyp.8281, 2011.

Gribb, M. M., Forkutsa, I., Hansen, A., Chandler, D. G., and McNamara, J. P.: The Effect of Various Soil Hydraulic Property Estimates on Soil Moisture Simulations, Vadose Zone J., 8, 321-331, doi:10.2136/vzj2008.0088, 2009.

Hanson, C., Burgess, M. D., Windom, J. D., and Hartzmann, R. J.: New Weighing Mechanism for Precipitation Gauges, J. Hydrol. Eng., 6, 75-77, doi:10.1061/(ASCE)1084-0699(2001)6:1(75), 2001.

Hanson, C., Pierson, F., and Johnson, G.: Dual-Gauge System for Measuring Precipitation: Historical Development and Use, J. Hydrol. Eng., 9, 350-359, doi:10.1061/(ASCE)10840699(2004)9:5(350), 2004.

Harr, R. D.: Effects of clearcutting on rain-on-snow runoff in western Oregon - a new look at old studies, Water Resour. Res., 22, 1095-1100, doi:10.1029/WR022i007p01095, 1986.

Hoffman, B. A.: Scale and heterogeneity in hydraulic properties of the fractured granitic Boise front, Boise, Idaho, M. Sc. Thesis, 51 pp., Dep. Of Geosci., Boise State University, available at: http://icewater.boisestate.edu/boisefront-products/other/ Publications/Hoffman_2008Thesis.pdf (last access: 15 April 2014), 2008.

Judson, A. and Doesken N.: Density of freshly fallen snow in the Central Rocky Mountains, B. Am. Meteorol. Soc., 81, $1577-$ 1587, doi:10.1175/1520-0477(2000)081<1577:doffsi>2.3.co;2, 2000 .

Kattelmann, R.: Flooding from rain-on-snow events in the Sierra Nevada, IAHS-AISH P., 239, 59-66, http://itia.ntua.gr/ hsj/redbooks/239/iahs_239_0000.pdf\#page=69 (last access: 15 April 2014), 1996.

Marks, D., Kimball, J., Tingey, D., and Link, T.: The sensitivity of snowmelt processes to climate conditions and forest cover during rain-on-snow: a case study of the 1996 Pacific Northwest flood, Hydrol. Process., 12, 1569-1587, doi:10.1002/(SICI)1099- 
1085(199808/09)12:10/11<1569::AID-HYP682>3.0.CO;2-L, 1998.

Marks, D., Domingo, J., Susong, D., Link, T., and Garen, D.: A spatially distributed energy balance snowmelt model for application in mountain basins, Hydrol. Process., 13, 1935-1959, doi:10.1002/(SICI)1099-1085(199909)13:12/13<1935::AIDHYP868>3.0.CO;2-C, 1999.

Marks, D., Winstral, A., Reba, M., Pomeroy, J., and Kumar, M.: An evaluation of methods for determining during-storm precipitation phase and the rain/snow transition elevation at the surface in a mountain basin, Adv. Water Resour., 55, 98-110, doi:10.1016/j.advwatres.2012.11.012, 2013.

McCabe, G. J., Clark, M. P., and Hay, L. E.: Rain-on-snow events in the western United States, B. Am. Meteorol. Soc., 88, 319-328, doi:10.1175/bams-88-3-319, 2007.

McNamara, J. P., Chandler, D., Seyfried, M., and Achet, S.: Soil moisture states, lateral flow, and streamflow generation in a semiarid, snowmelt-driven catchment, Hydrol. Process., 19, 40234038, doi:10.1002/hyp.5869, 2005.

Miller, C. R., Routh, P. S., Brosten, T. R., and McNamara, J. P.: Application of time-lapse ERT imaging to watershed characterization, Geophysics, 73, G7-G17, doi:10.1190/1.2907156, 2008.

Morin, S., Lejeune, Y., Lesaffre, B., Panel, J.-M., Poncet, D., David, P., and Sudul, M.: An 18-yr long (1993-2011) snow and meteorological dataset from a mid-altitude mountain site (Col de Porte, France, $1325 \mathrm{~m}$ alt.) for driving and evaluating snowpack models, Earth Syst. Sci. Data, 4, 13-21, doi:10.5194/essd-4-13-2012, 2012.

Mote, P. W.: Trends in snow water equivalent in the Pacific Northwest and their climatic causes, Geophys. Res. Lett., 10, 1601, doi:10.1029/2003GL017258, 2003.

Nayak, A., Chandler, D. G., Marks, D., McNamara, J. P., and Seyfried, M.: Correction of electronic record for weighing bucket precipitation gauge measurements, Water Resour. Res., 44, W00D11, doi:10.1029/2008wr006875, 2008.

Nayak, A., Marks, D., Chandler, D. G., and Seyfried, M.: Long-term snow, climate, and streamflow trends at the Reynolds Creek Experimental Watershed, Owyhee Mountains, Idaho, United States, Water Resour. Res., 46, W06519, doi:10.1029/2008wr007525, 2010.

Nolin, C. W. and Daly, C.: Mapping "at risk" snow in the Pacific Northwest, J. Hydrometeorol., 7, 1164-1171, doi:10.1175/jhm543.1, 2006.

O'Loughlin, E. M.: Saturation regions in catchments and their relations to soil and topographic properties, J. Hydrol., 53, 229-246, 1981

O'Loughlin, E. M.: Predictions of surface saturation zones in natural catchments by topographic analysis, Water Resour. Res., 22, 794-804, doi:10.1029/WR022i005p00794, 1986.

Reba, M. L., Marks, D., Seyfried, M., Winstral, A., Kumar, M., and Flerchinger, G.: A long-term data set for hydrologic modeling in a snow-dominated mountain catchment, Water Resour. Res., 47, W07702, doi:10.1029/2010WR010030, 2011.

Reba, M. L., Pomeroy, J., Marks, D., and Link, T. E.: Estimating surface sublimation losses from snowpacks in a mountain catchment using eddy covariance and turbulent transfer calculations, Hydrol. Process., 26, 3699-3711, doi:10.1002/hyp.8372, 2012.
Seyfried, M., Hanson, C., Murdock, A., and Van Vactor, S.: Longterm lysimeter database, Reynolds Creek Experimental Watershed, Idaho, United States, Water Resour. Res., 37, 2853-2856, doi:10.1029/2001WR000413, 2001a.

Seyfried, M., Flerchinger, G., Murdock, M., Hanson, C., and Van Vactor, S.: Long-term soil temperature database, Reynolds Creek Experimental Watershed, Idaho, United States, Water Resour. Res., 37, 2843-2846, doi:10.1029/2001WR000418, 2001b.

Shallcross, A.: LiDAR Investigations of Snow Distribution in Mountainous Terrain, M.S. thesis, 62 pp., Dep. of Geosci., Boise State University, http://scholarworks.boisestate.edu/td/349/ (last access: 15 April 2014), 2012.

Smith, T. J., McNamara, J. P., Flores, A. N., Gribb, M. M., Aishlin, P. S., and Benner, S. G.: Small soil storage capacity limits benefit of winter snowpack to upland vegetation, Hydrol. Process., 25, 3858-3865, doi:10.1002/hyp.8340, 2011.

Streutker, D. R. and Glenn, N. F. LiDAR measurement of sagebrush steppe vegetation heights, Remote Sens. Environ., 102, 135-145, doi:10.1016/j.rse.2006.02.011, 2006.

Sui, J. and Koehler, G.: Rain-on-snow induced flood events in Southern Germany, J. Hydrol., 252, 205-220, doi:10.1016/s0022-1694(01)00460-7, 2001.

Surfleet, C. G, and Tullos, D.: Variability in effect of climate change on rain-on-snow peak flow events in a temperate climate, J. Hydrol., 479, 24-34, doi:10.1016/j.jhydrol.2012.11.021, 2013.

Tesfa, T. K., Tarboton, D. G., Chandler, D. G., and McNamara, J. P.: Modeling soil depth from topographic and land cover attributes, Water Resour. Res., 45, W10438, doi:10.1029/2008WR007474, 2009.

Western, A. W. and Grayson, R. B.: The Tarrawarra data set: Soil moisture patterns, soil characteristics, and hydrological flux measurements, Water Resour. Res., 34, 2765-2768, doi:10.1029/98wr01833, 1998.

Williams, C. J., McNamara, J. P., and Chandler, D. G.: Controls on the temporal and spatial variability of soil moisture in a mountainous landscape: the signature of snow and complex terrain, Hydrol. Earth Syst. Sci., 13, 1325-1336, doi:10.5194/hess-131325-2009, 2009.

Winstral, A. and Marks, D.: Long-term snow distribution observations in a mountain catchment: Assessing variability, time stability, and the representativeness of an index site, Water Resour. Res., 50, 293-305, doi:10.1002/2012WR013038, 2014.

Winstral, A., Marks, D., and Gurney, R. Simulating wind-affected snow accumulations at catchment to basin scales, Adv. Water Resour., 55, 64-79, doi:10.1016/j.advwatres.2012.08.011, 2013.

Yenko, M.: Hydrometric and Geochemical Evidence of Streamflow Sources in the Upper Dry Creek Experimental Watershed, Southwestern Idaho, M.S. thesis, 116 pp., Dep. of Geosci., Boise State University, http://earth.boisestate.edu/ drycreek/publications/, 2003. 